\title{
Openness, Libraries and Political Transformation
}

\author{
Nikolaus Hamann \\ Vienna Public Libraries, Association of Critical Librarians in Austria, Vienna, Austria, niko- \\ laus.hamann@gmx.at,www.kribibi.at
}

\begin{abstract}
Since mankind developed written documents, libraries have been the places where information and knowledge have been stored. At the same time there have always been struggles about the access to information and knowledge. Within a digitized world libraries have to re-define their position. The demand for access for all, made by scientists and researchers as well as the public, presents libraries with a new challenge. This article tries to show how libraries can meet that challenge, what requirements they need to be successful, and where the limits are within bourgeois society.
\end{abstract}

Keywords: libraries, openness, open access, North-South relations, political transformation

\section{Introduction}

"Privatization and shortage are obstructive and have no more justification when we struggle for viability. In contrast the parole should be: Abolition of all patents! Freedom for ingenuity! Copy globally and without restraint! Utilize what is useful! Break down the tollbooths! Disempower the highwaymen claiming tariffs from you when you want to educate yourselves!

Such cries would have been ultra-radical phrases 20 years ago. But today the technical resources are at hand to re-organize the whole of important [...] knowledge, so that as many as possible understand to spread it so all mankind can use it free of charge and present it in a way that enables to change it for own purposes. Those representations are in the common interest of mankind. Therefore they should explicitly be at disposal for copying and adapting. What today is hindered by strong efforts, spreading knowledge free of charge, should become the explicit aspiration. What from a bourgeois perspective looks like a gigantic raid, would in fact be a pilgrimage for the common good"1 [Translation N.H.]

These words by Hans Thie, economy speaker of The Left Party in Germany's 'Bundestag', were originally made in an ecological context. But they can be used without changes for the 'Spirit of Openness' in science and arts, because "within solely intellectual production, where intellectual work is not only means but the purpose of economic activity, the bourgeois conditions fundamentally begin to slip. The existing economic rules start to stagger and at the same time their bourgeois forms. Everything is changed. The spirit is a free commonist, not an elitist citizen"2

\footnotetext{
1 „Privatisierung und Verknappung sind hinderlich und haben spätestens dann keine Berechtigung mehr, wenn es ums Überleben geht. Stattdessen sollten die Parolen gelten: Aufhebung aller Patente! Freiheit für den Erfindergeist! Kopiert global und schrankenlos! Macht Euch zu Diensten was Euch nützlich ist! Schleift die Mautstellen! Entmachtet die Wegelagerer, die von Euch Zölle verlangen, wenn Ihr Euch bilden wollt! Solche Appelle wären noch vor 20 Jahren ultraradikale Phrasen gewesen. Heute dagegen stehen die technischen Mittel bereit, um die Gesamtheit des [...] wichtigen Wissens so aufzubereiten, dass es möglichst viele verstehen, es so zu verbreiten, dass es alle Erdenmenschen unentgeltlich nutzen können, und so zu präsentieren, dass die Veränderung für eigene Zwecke möglich ist. Solche Darstellungen und Verbreitungen liegen im gemeinsamen Interesse der Menschheit. Deshalb sollten sie ausdrücklich mit dem Zweck des Kopierens und Adaptierens zur Verfügung stehen. Was man heute mit großem Aufwand zu verhindern versucht oder nur stillschweigend duldet, die Verbreitung ohne Zahlung, sollte zum expliziten Ziel werden. Was vom bürgerlichen Standpunkt wie ein gigantischer Raubzug aussieht, wäre tatsächlich eine Wallfahrt für das gemeinsame Wohl“. Source: http://www.rosalux.de/fileadmin/rls_uploads/pdfs/sonst_publikationen/VSA_Thie_Rotes-Gruen.pdf, page 99f.

2 „bei rein geistiger Produktion, also dort, wo geistige Betätigung nicht nur Mittel, sondern Selbstzweck des Wirtschaftens ist, kommen die bürgerlichen Verhältnisse grundlegend ins Rutschen. Hier wanken die bisherigen Gesetze der Ökonomie und zugleich ihre bürgerlichen Formen. Hier ist tendenziell alles anders. Der Geist ist
} 
As Thie writes, in the economy of the mind the principle is fundamental that knowledge can be the more productive the more it is universal and the more it can be freed from bourgeois proprietorship. Openness as a political concept means to look at the results of science and arts not mainly in their commodity form but as worldwide social property.

However, that doesn't mean that bourgeois conditions will slide quasi automatically into a new, whatever one will call it society, because - as the initiatives of many corporate open access publishers show - such models can easily be implemented based on the logic of capitalist valorisation. Also the engagement of stock exchange speculator George Soros in the Open Access movement indicates this circumstance. But definitely the Open Access concept contains an emancipatory function and implies the quest for democratizing society because knowledge and works of art are this way spread easier and faster. The Arbitrary behaviour of publishers and censorship are less likely. The Open Access (OA) concept promotes worldwide communication and gives developing countries better chances to participate in the production of and access to the world's knowledge. If Openness also includes political decisionmaking and administrative actions, it promotes transparency and enables citizens to have more influence on creating their living conditions.

\section{Open Access as Part of the Openness Concept}

To make available intellectual products via the Internet and the WWW as a public good is the crucial tenor of Openness in a digitized world. It can be reached in different ways and have different effects (Open Access, Open Data, Open Science, Open Source ...). In this article especially Open Access shall be illuminated because it has the highest relevance for libraries.

"The idea of Open Access corresponds fully to the traditional values and goals of academic working, which rely on colleagueship, exchange of ideas and outputs, the common search for insight and the spread of knowledge for the benefit of society. Only the digital age allows a free common approach to scientific knowledge and research data that was not known under the conditions of the printing age. Instrumental for this is the impact of this new instrument on the development of a society committed to the central concept of Open Scholarship and Open Knowledge"33 [Translation N.H.].

Even if the idea of Open Access may have been present in the brains of avant-garde scientists, the substantial trigger for the Open Access movement was the crisis of journals at the end of $20^{\text {th }}$ century. The price increase of scientific journals between 1986 and 2000 amounted to 226 per cent ${ }^{4}$. Because of these increases the budgets of libraries were used for up to 90 per cent only for journal subscriptions, so that libraries had to cancel several subscriptions thus downgrading the informational access for science and education. This led to different initiatives, mainly the "Budapest Open Access Initiative (BOAI)" in $2002^{5}$, the "Bethesda Statement on Open Access Publishing" in $2003^{6}$ and the "Berlin Declaration on Open Access to Knowledge in the Sciences and Humanities", also in $2003^{7}$. The large great library associations EBLIDA (European Bureau of Library Information and Documentation Associa-

\footnotetext{
freier Commonist, nicht elitärer Bürger".

http://www.rosalux.de/fileadmin/rls uploads/pdfs/sonst_publikationen/VSA Thie Rotes-Gruen.pdf, page $100 f$.

${ }^{3}$ „Die Idee des Open Access entspricht ganz den traditionellen Werten und Zielen akademischen Arbeitens, das auf Kollegialität, dem Austausch von Ideen und Ergebnissen, der gemeinsamen Suche nach Erkenntnis und der Verbreitung von Wissen zum Wohle der Gesellschaft insgesamt beruhen. Erst das digitale Zeitalter ermöglicht einen gemeinsamen freien Zugang zu wissenschaftlicher Erkenntnis und zu Forschungsdaten, wie er zuvor unter den Bedingungen des Druckzeitalters nicht denkbar war. Entscheidend dabei ist die Auswirkung dieses neuen Instruments auf die Entwicklung einer Gesellschaft, die den Leitbegriffen von Open Scholarship und Open Knowledge verpflichtet ist“, http://www.faz.net/aktuell/beruf-chance/campus/open-access-es-wird-zeit-alle-alleslesen-zu-lassen-1639084.html

${ }^{4}$ http://www.hbz-nrw.de/dokumentencenter/tagungen/berlin6/Folie_Mueller_hbz_11112008.pdf

5 http://www.budapestopenaccessinitiative.org/read

6 http://www.earlham.edu/\%7Epeters/fos/bethesda.htm

7 http://www.zim.mpg.de/openaccess-berlin/berlindeclaration.html
} 
tions) $^{8}$ and IFLA (International Federation of Library Associations) ${ }^{9}$ published resolutions supporting Open Access strategies.

The goal of all Open Access initiatives is to make knowledge and information in digital form accessible to and utilizable for everyone and to do so permanently, free of charge and without technical or legal barriers. The idea is that this form of access can act as a stimulus for science as well as the development of mankind. But there are differences concerning the extension of Open Access'. The minimum demand is to make the results of tax funded research open access, whereas the maximum demand also covers research conducted by companies, universities and universities of applied sciences. Having in mind the maximum demand, the limits of current Open Access policies very quickly become evident. Imagine for example the problems involved and resistances one would face when trying to make e.g. the pharmaceutical industry's research data Open Access.

One certainly should reflect in different ways on the amplitude between minimal and maximum demand. This article does not want to list all arguments, but only wants to point out some basic reflections. Representatives of the minimum demand argue that most scientific research is conducted in public or tax funded institutions and that it is not reasonable that the public should pay twice or, if you add the peer review system, three times, while the publishers make unjustifiably high profits. Supporters of the maximum demand argue that all results of scientific and artistic works build on the efforts of others or refer to those efforts, being therefore a product of social collaboration, as Robert K. Merton stressed, that should belong to all.

Open Access very often is compared to Open Source, but there are significant differences. While Open Source's main character is the cooperation of many persons participating in a project, collaboration is - depending on the scientific discipline - not so commonly occurring in the world of OA. Also the concepts of openness differ:

"While Open Source makes as principal claims a. the disposability of software's source code, b. the possibility to use and copy software free of charge, c. the possibility to change software and pass on the changed version, the degree of Open Access' openness is discussed controversially and has basically two forms. While Gratis Open Access is defined relatively undisputed as access free of charge to scientific documents, Libre Open Access is defined as free of charge access that nullifies at least one legal barrier of the use of scientific documents" ${ }^{\prime 10}$ [Translation N.H.]. Only Libre Open Access enables the reworking and passing on of the reworked version to others.

Open Access (as all the other concepts of Openness) cannot be valid in the same way for science and the arts. While scientists as a general rule can do their work in a (more or less) assured position, freelance artists are dependent on the possibility to market their products. So it will be necessary to reform copyright and similar rules that apply to the creative sectors of the economy or to arrange the living conditions of artists in a completely new way, for example by introducing a basic income guarantee.

\section{Libraries and Open Access}

Open Access knows two ways of how knowledge and information can be made accessible to everybody free of charge and without legal or technical barriers for all times. One of those, the golden road, is the more fundamental approach: new research results shall be published

\footnotetext{
${ }^{8}$ http://ec.europa.eu/research/era/pdf/european-bureau-of-library-information-documentation-associationseblida_en.pdf

${ }_{9}^{9}$ http://www.ifla.org/publications/ifla-statement-on-open-access-to-scholarly-literature-and-research- documentation

${ }^{10}$ „Während Open Source als Kernforderung a. die Verfügbarkeit des Quelltextes einer Software, b. die Möglichkeit, die Software entgeltfrei zu kopieren und zu nutzen, c. die Möglichkeit, die Software zu verändern und in veränderter Form weiterzugeben kennt, wird der Grad der Offenheit bei Open Access kontrovers diskutiert und kennt im Wesentlichen zwei Ausformungen. Während Gratis Open Access relativ eindeutig als entgeltfreier Zugang zu wissenschaftlichen Dokumenten definiert ist, wird Libre Open Access definiert als entgeltfreier Zugang, der zumindest eine Rechtebarriere der Dokumentnutzung/ -verwendung aufhebt“, http://eprints.rclis.org/17183/1/Herb_mit_Deckblatt.pdf, page. 33.
} 
right from the beginning exclusively in Open Access Journals, funded by the authors or by the institutional membership of universities or research units. At the moment many scientists advocate the golden road theoretically, but hardly use it themselves. They mainly still publish in the old Toll Access Journals, which has to do with the hierarchy of journal reputation present in the academic system.

The green road has a more moderate approach, which is likely to have more success. Here the research results are published in a conventional journal, but after a negotiated period they may be published on the researchers' websites or in a repository provided either by the scientist's institution or an institution that represents an entire research field.

Libraries and librarians enter the game at the point where access to academic knowledge is established because their professional knowledge makes librarians and libraries the perfect location. Libraries also have a lot of experience in digitizing their holdings as well as in long-term archiving.

Librarians for ages were concerned with segregating valuable from not so valuable documents, to classify them, to set keywords and to enrich catalogue data with meta-data. Compared to traditional library magazines, the nearly limitless memory of a server will make it possible for the first time to store all data worthy of preservation for coming generations, given that the problems of long-term preservation can be solved adequately. Librarian can also handle another task that is crucial for the reasonable use of Open Access very well: the training of (digital) information competence. They have already done son for centuries.

It must be clear that libraries cannot conduct the re-arrangement towards Open Access themselves without any support. This task is rather a political one because the social benefits clearly exceed the public investments. Substantial additional funds are dearly needed, especially as no one knows today if libraries can reduce their costs by Open Access projects, although Peter Suber from the Harvard Office of Scholarly Communication is convinced that "OA solves the pricing crisis for scholarly journals. It also solves what I've called the permission crisis. OA also serves library interests in other, indirect ways. Librarians want to help users find the information they need, regardless of the budget-enforced limits on the library's own collection. Academic librarians want to help faculty increase their audience and impact, and help the university raise its research profile"11.

Libraries are principally open-minded to Open Access strategies, but they have to face barriers that did not exist in times before digitization. When a library bought a book or made a subscription to a journal, they owned the physical book or magazine afterwards and were allowed to freely lend them. With e-books and e-journals the library can only attain a license and the publisher still has the right to determine in which way the library may make it accessible to the public. Private legal relations therefore hamper the technically possible free use. Furthermore the virtual books and journals cannot be archived.

Another huge problem for libraries is the strategy of publishers to bundle up magazines a library needs dearly with others it does not want to have, and to make subscriptions possible only to those bundles. Public libraries face the problem that publishers often refuse to provide licenses for e-books, especially for bestsellers. If libraries can get licences for such popular works, they often are limited to an absurdly small number of loans. As described above, the problem is that publishers always have the right to dictate how public libraries work.

These problems cannot be solved unless copyright rules are adopted for modern times. But it is necessary to see how in a capitalist world technical advance can have negative results for the public if society is not able to shape positive circumstances for their own benefit.

\section{The Limits and Critique of Open Access}

It is mainly publishers and other economic stakeholders who are critical of Open Access strategies. Their first concern is the possible loss of a highly profitable business field and therefore refutable from a political viewpoint. But academics often support this argument either from a traditional point of view or by utilising the argument that Open Access Publishing

\footnotetext{
${ }^{11}$ http://legacy.earlham.edu/ peters/fos/overview.htm
} 
does not have the same reputation as plain old Toll Access Journals that have high impact factors. Some also argue that publishing Open Access hampers their academic careers.

Companies are mainly interested in applied research and fear because of competition and the profit-focus that in an Open Access world they would not be able to keep their research results secret. But the economy also derives profits from having fast and costless access to information. Exactly here is the point where the discussion has to be developed either in the direction of a further stage of bourgeois democracy or a new model of society.

Also the political Left expresses criticism of Open Access strategies. Some of its representatives criticise on the one hand the ideological foundation of Open Access within the imperialistic discourse of development aid and on the other hand that Open Access as a technical solution is not able to solve existing social disparities. "The current definition of the Gold Road of Open Access shows that especially the big publishing houses have very well understood to use Open Access for themselves and for their continued supremacy. While at first the Golden Road only meant to publish scientific results openly and freely (in opposite to the Green Road, where contributions can be openly published only after they have been exclusively marketed by private publishers), the Golden Road nowadays is understood predominantly in such a way that publishers organize the open and free primary publication after a publishing fee has been paid. [...] [Such Left positions argue for the] industrial workers, consumers and other creators' fair participation in the results" ${ }^{12}$ [translation N.H.].

In the realm of academia, one can often hear the argument that introducing a duty academics working in public institutions to publish Open Access would violate the constitutional freedom of research and teaching. This is a false conclusion because nobody can be forced to publish the results of his/her work, but if one wants to publish them, it has to be done Open Access, at least within the framework of the EU Horizon 2020 programme that will start in 2014.

Scholars' insecurities about publishing Open Access partly also come from the fact that the distribution of rights is not clearly regulated. As long as scientists, researchers, libraries and the public have no legal claim for free access to new and relevant information, as long as Open access is a voluntary offer by the publishers that can be changed or withdrawn at all times, it will not gain the reputation and breadth necessary for fundamentally changing the momentary publishing regime.

In discussions of Green Open Access, mainly the duration of the holdback period is a crucial question. Publishers call for preferably long periods, while large parts of the academic world and the public demand open access without any delay.

\section{Open Access and North-South Relations}

The close link between scientific development and the social and economic wellbeing of a nation has long been recognised. Jawaharlal Nehru, India's first prime minister, said: "It is science alone that can solve the problems of hunger and poverty, of insanitation and illiteracy [...] Who indeed can ignore science today? We need it at every turn". Likewise, a 1982 UNESCO report states that "assimilation of scientific and technological information is an essential precondition for progress in developing countries". The InterAcademy Council argues: "In a world moving rapidly toward the knowledge-based economies of the 21 st cen-

\footnotetext{
12 „[Es]zeigt die aktuelle Definition der Golden Road des Open Access, dass es gerade die großen Wissenschaftsverlage sind, die es sehr genau verstanden haben, Open Access für sich und damit für eine weitergehende Vormachtstellung zu nutzen. War mit der Golden Road ursprünglich nur gemeint, Wissenschaftliche Beiträge offen und frei erstzuveröffentlichen (im Gegensatz zur Green Road, der freien und offenen Zweitveröffentlichung nach einer exklusiven Vermarktung der Beiträge durch privatwirtschaftliche Verlage), wird "golden" mittlerweile mehrheitlich so verstanden, dass privatwirtschaftliche Verlage nach Zahlung einer Publikationsgebühr die offene und freie Erstveröffentlichung der wissenschaftlichen Beiträge organisieren."

Eingefordert wird eine „faire[n] Teilhabe der Fabrikbelegschaften, KonsumentInnen oder anderen IdeengeberInnen an den Ergebnissen.", http://blog.die-linke.de/digitalelinke/ohne-gleichberechtigung-und-sozialen-ausgleichbleibt-open-dicht/
} 
tury, capacity building in science and technology (S\&T) is necessary everywhere. But the need is greatest for the developing countries"13

As already mentioned in section 4, Openness and Open Access play an important role in the discussion of just and fair relations between Northern and Southern countries. But often this takes on the meaning that Northern states in a (post-) imperialist attitude should let the developing countries participate in Western information and knowledge. Developing countries tend to not like this view for obvious reasons and argue with strong credentials why the time has come for Open Access and Open Archiving.

Of course it is true that Southern countries depending on their financial situation have less possibilities to bear the exorbitant costs of traditionally or digitally stored knowledge and information. Also their research budgets tend to be smaller. But Southern countries have to offer huge amounts of knowledge that has until now not been appreciated enough in the world. This is especially the case in the fields of health, agriculture and climate. A just exchange of knowledge enabled by Open Access strategies therefore would be beneficial for the North too.

Developing countries' educational and research systems often have, as an outcome of imperialism and colonialism, conservative structures. Nevertheless countries like for example Brazil have a much higher presence of Open Access Journals and a much higher number of articles published open access than some countries in the North. Therefore structural learning and exchange can be profitable and worthwhile for both sides.

\section{Résumé from a (Left) Librarian's View}

"The debate on the value of open access to publicly funded research information is now migrating from 'whether' to 'how'"14. The debate on Open Access strategies has reached such a broad level that an implementation is necessary in any case, independently if we speak about a reform of publishing within bourgeois society or about a process that is part of the transformation of political conditions.

Hendrik Bunke compares the mainstream of the Open Access debate with the "Revisionismus-Debatte" (Revisionist Debate) in Germany's Social Democracy in 1914" "The starting point is my amazement about the quiescence of German libraries regarding the boycott of Elsevier. Maybe somehow unreflected and naïve I had assumed until now, that we all fight for the enforcement of Open Access and therefore would be highly pleased by the boycott that is a rebellion of the scientists from below. Think again. The reactions were restrained. Only few librarians (the usual suspects) participated in the debate, let alone the boycott. Public statements by libraries were rare. This is even more surprising as the issue found broad attention in the media. It surprises also because the issue Open Access has been established quite well in the library field and is promoted actively by investors and their associated institutions. But also the protagonists of this slow transition remain silent or sceptical.

Why this reluctance? For years we have preached the advantages and necessity of Open Access. Every day we work hard to build the infrastructure for it. We complain that we get through very slowly to the academics, that we succeed only insufficiently to convince them. And then (finally!) a large number of academics becomes active and declares not to write or review anymore for Elsevier because they think this publisher's business model and prices are exploitative. This creates new wind for Open Access that reaches the media, politics and governments (EU, UK). And we? We stand aside and look at it lukewarm and with at least sceptical nosiness.

One reason is - similar to the SPD [Social Democratic Party of Germany] before 1914 the acceptance and integration of Open Access. Since the Berlin Declaration - virtually our Erfurt Programme - we have reached a lot. One can say so. But apparently we become now somehow ... cushy. And we become the victim of our own success. Libraries and Open Ac-

\footnotetext{
${ }_{13}^{13} \mathrm{http}: / /$ www.scidev.net/global/communication/feature/open-access-archiving-the-fast-track-to-building-r.html

14 http://www.scidev.net/global/communication/feature/open-access-archiving-the-fast-track-to-building-r.html
} 
cess protagonists have made themselves cosy in their small niche. Mainly anxious to save what has been reached, they merely aspire, to expand their stake on the basis of market laws. They cheerfully cooperate with the publishers in many areas - also in the fields of Open Access - and try not to hurt one another. It's nice to sit at the same table with the almighty, isn't it?" 15 [Translation N.H.].

Underlying the debate on Open Access is the categorical question to whom knowledge belongs. This question leads directly to disputes about "intellectual property", which is a deeply ethical and political conflict.

"[There can be] a whole series of reasons indicating that issues preserving the so called 'intellectual property'

- hamper the growth of the economy and make possible only a suboptimal level of prosperity, because by protecting 'intellectual property' only a suboptimal allocation of knowledge is possible in order to raise the effectiveness and efficiency of dealing with scarce goods;

- contribute to the reproduction or actual strengthening of social inequality;

- because of the technical requirements necessary for enforcement, promote illiberal and totalitarian developments" ${ }^{16}$ [Translation N.H.]

At a whole the development of intellectual property rights shows that there is a steady trend towards strengthening the rights of organizations that want to economically valorise information. At the same time the rights of the creators, the users and the public tend to be less recognised. The parallelogram of forces, installed as a just equilibrium between

15 http://www.hbxt.org/2012/11/open-access-und-revisionismus.html: "Ausgangspunkt ist meine Verwunderung über die Stille im Wald der deutschen Bibliotheken im Bezug auf den Elsevier-Boykott. Etwas unreflektiert und vielleicht naiv war ich bis dato davon ausgegangen, dass wir alle doch für die Durchsetzung von Open Access kämpfen und deshalb hocherfreut über den Boykott, letztlich ein Aufstand der WissenschaftlerInnen 'von unten', sein müssten. Falsch gedacht. Die Reaktionen waren sehr verhalten. Nur wenige Bibliothekarlnnen (die üblichen Verdächtigen) beteiligten sich überhaupt an der Debatte, geschweige denn am Boykott. Öffentliche Stellungnahmen von Bibliotheken waren nur sehr wenig zu finden. Das verwundert, auch wegen der auch in Deutschland doch recht großen medialen Aufmerksamkeit für das Thema. Es verwundert auch deshalb, weil das Thema Open Access sich in den letzten zehn Jahren in der Bibliothekenszene sehr wohl etabliert hat und auch aktiv gefördert wird durch Geldgeber und anhängende Institutionen. Aber auch die Protagonisten dieses langsamen Wandels schweigen größtenteils oder äußern sich sogar skeptisch.

Warum diese Zurückhaltung? Wir predigen seit Jahren die Vorzüge und Notwendigkeit von Open Access. Wir arbeiten tagtäglich hart daran, die Infrastruktur dafür aufzubauen. Wir beklagen uns, dass wir damit bei den WissenschaftlerInnen nur sehr langsam durchdringen, dass es uns nur unzureichend gelingt, sie zu überzeugen. Und dann wird (endlich!) eine sehr große Zahl von WissenschaftlerInnen aus aller Welt aktiv und erklärt, nicht mehr für Elsevier Journals schreiben oder reviewen zu wollen, weil sie Geschäftsmodell und Preise des Verlages für ausbeuterisch halten, erzeugt damit neuen Wind für Open Access, der es in die Medien, Politik und Staatsapparate (UK, EU) schafft. Und wir? Stehen daneben und schauen uns das Ganze mäßig interessiert und mit maximal skeptischer Neugierde an?

Einen Grund findet mensch - ähnlich wie bei der SPD vor 1914 - in der Akzeptanz und Integration von Open Access. Wir haben seit der Berliner Erklärung von 2003 - quasi unser Erfurter Programm - ja schließlich vieles erreicht. Kann man ja mal sagen. Aber offenbar werden wir da nun auch etwas... bequem. Und wir werden das Opfer unseres eigenen Erfolges. Die meisten deutschen Bibliotheken und OA-Protagonisten haben es sich in ihrer kleinen Nische gemütlich gemacht. Im Wesentlichen bemüht, das wenige bisher Erreichte zu erhalten, streben sie lediglich danach, auf Grundlage der Gesetze des Marktes ihren Anteil daran ein wenig auszubauen. Mit den Verlagen wird auf vielen Ebenen - auch im Open Access Bereich - fröhlich kooperiert und man ist dabei bemüht, sich bloß nicht irgendwie wehzutun. Ist ja auch ganz schön, mit den Mächtigen mal an einem Tisch sitzen".

${ }^{16}$ http://www.wissen-schaft.org/storage/files/konzept/60f617d9f21f4c86319d388219e03767.pdf: „[...] eine ganze Reihe von Gründen angeführt werden, die darauf hinweisen, dass Institutionen zum Schutz so genannten , geistigen Eigentums'

- das Wirtschaftswachstum insgesamt eher hemmen und daher nur ein suboptimales Wohlstandsniveau ermöglichen, da durch den Schutz von so genanntem ,geistigen Eigentum' nur eine suboptimale Allokation von Wissen zur Steigerung von Effektivität und Effizienz im Umgang mit knappen Gütern möglich ist;

- zur Reproduktion oder gar Verstärkung sozialer Ungleichheit beitragen;

- aufgrund der technischen Voraussetzungen, die zu ihrer Durchsetzung notwendig sind, antiliberale- bzw. totalitäre Entwicklungen begünstigen“. 
creators, utilizers, users and the public, has lost its balance. However, equity is one of the basic themes of ethics, equally to the enablement of a "good life" for all in a philosophical as well as socio-economic perspective.

I want to stress as a human to whom arts and culture are very important as well as a librarian at a public library who is as a matter of principle interested in conditions that enable artists to be creative without economic distress, that Open Access strategies cannot be applied one to one on artistic production. The copyright regime ("the labour legislation of creative people") ${ }^{17}$ has to be changed in a way that all artists for the first time (!) have a chance to lead a "good life".

\section{About the Author}

\section{Nikolaus Hamann}

Born in 1953; librarian in the Vienna Public Libraries since 1991. Since 1992 he is member of the Association of Critical Librarians in Austria (KRIBIBI) [www.kribibi.at]. He has organised numerous workshops and conferences for the association. He has given numerous lectures and presentations and has written numerous articles on library issues. Since 2011, he is member of the coordinating board of the association. He is member of the managing committee of the Federation of Austrian Librarians (VÖB) [www.univie.ac.at/voeb], member of the organisation committee of the international conference "Freedom of Information under Pressure. Control - Crisis - Culture" that will take place in Vienna on February $28^{\text {th }}$ and March $1^{\text {st }}, 2014$ (www.freedom-of-information.info).

\footnotetext{
${ }^{17}$ http://www.blaetter.de/archiv/jahrgaenge/2009/november/die-zukunft-des-wissens
} 